Article

\title{
Improved Performance of Ternary Solar Cells by Using BODIPY Triads
}

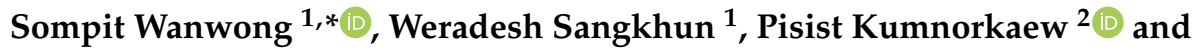 \\ Jatuphorn Wootthikanokkhan ${ }^{1}$ \\ 1 Materials Technology Program, School of Energy, Environment and Materials, King Mongkut's University of \\ Technology Thonburi, 126 Pracha Uthit Road, Bang Mod, Thung Khru, Bangkok 10140, Thailand; \\ weradesh.s@mail.kmutt.ac.th (W.S.); Jatuphorn.woo@kmutt.ac.th (J.W.) \\ 2 National Nanotechnology Center, National Science and Technology Development Agency, \\ 111 Thailand Science Park, Pathum Thani 12120, Thailand; pisist@nanotec.or.th \\ * Correspondence: sompit.wan@kmutt.ac.th
}

Received: 13 May 2020; Accepted: 13 June 2020; Published: 15 June 2020

check for updates

\begin{abstract}
Two boron dipyrromethene (BODIPY) triads, namely BODIPY-1 and BODIPY-2, were synthesized and incorporated with poly-3-hexyl thiophene: $(6,6)$-phenyl-C61-butyric acid methyl ester (PCBM) P3HT:PCBM. The photovoltaic performance of BODIPY:P3HT:PCBM ternary solar cells was increased, as compared to the control binary solar cells (P3HT:PCBM). The optimized power conversion efficiency (PCE) of BODIPY-1:P3HT:PCBM was improved from 2.22\% to $3.43 \%$. The enhancement of PCE was attributed to cascade charge transfer, an improved external quantum efficiency (EQE) with increased short circuit current $\left(\mathrm{J}_{\mathrm{sc}}\right)$, and more homogeneous morphology in the ternary blend.
\end{abstract}

Keywords: BODIPY; P3HT; PCBM; ternary solar cells; power conversion efficiency; morphology

\section{Introduction}

A power conversion efficiency (PCE) of bulk heterojunction solar cells of over $13 \%$ has been achieved through remarkable progress in the development of narrow gap polymers and non-fullerene acceptors [1-11]. Nevertheless, a single polymer cannot absorb the entire electromagnetic range of the sun spectrum, thus, limiting the amount of photon harvesting capabilities of those solar cells. To solve this issue, tandem solar cells, composed of stacking layers of different chromophores that display complementary absorption to each other, have been demonstrated [1,12,13]. Although tandem cells can improve efficiency up to $17 \%[14,15]$, their fabrication process is still complicated and comparatively expensive [12,16-18].

Another promising solar cell that can retain the advantages from of bulk heterojunction solar cells and tandem solar cells is the ternary solar cells [19-21]. A ternary system offers several advantages including: (a) Light harvesting can be improved by the complementary absorption of the third component. (b) Photovoltaic parameters, short circuit current $\left(\mathrm{J}_{\mathrm{Sc}}\right)$, open circuit voltage $\left(\mathrm{V}_{\mathrm{oc}}\right)$, and fill factor (FF), can be optimized by varying the ratio of donor or acceptor moieties. (c) The morphology and phase separation of the active layer, which play a key role in determining the efficiency, can be adjusted and controlled. (d) The fabrication method is easier than those of multi-layer or tandem solar cells [17,21-24]. To date, ternary solar cells provide a PCE of up to 12\% [21]. Typically, an active layer of ternary solar cells contains a donor (D), an acceptor (A), and a third component. The third component can be either a polymer or a small organic compound that serves as a donor or acceptor. Thereby, ternary solar cells are classified as two donors/one acceptor (D1/D2/A) or and one donor/two acceptors (D/A1/A2) $[17,22,25,26]$. It has been reported that ternary solar cells based on polymer/small 
organic molecule/fullerene are more effective than those based on polymer/polymer/fullerene. This is because the latter system tends to have difficulty in controlling crystallinity and phase separation, leading to micrometer scale domain formation [27-29].

Small organic compounds are beneficial as they have well-defined structures, precise molecular weight and high purity $[1,19,30,31]$. Several organic molecules or dyes that show long wavelength absorption and near-infrared (NIR) absorption have been investigated for use in ternary solar cells. In particular, blending small molecules with poly-3-hexyl thiophene (P3HT), a standard donor that has $\mathrm{J}_{\mathrm{sc}}$ and $\mathrm{V}_{\mathrm{oc}}$ limits with a band gap of $\sim 2.0 \mathrm{eV}$, have gained attention. Several groups have blended small organic compounds with $\mathrm{P} 3 \mathrm{HT}$ either to improve absorption range or to control phase separation. For examples, An et al. blended a 2-D conjugated small molecule, SMPV1, in P3HT:PC 71 BM and found that SMPV1 can extend the light absorption of the ternary system, resulting in increased photon harvesting in the longer wavelength region. They found that the PCE of ternary solar cells was increased from $3.35 \%$ to $4.06 \%$. This was due to the improvement of $\mathrm{J}_{\mathrm{sc}}$ and $\mathrm{FF}$ [32]. Hao et al. mixed a small molecule of p-DTS(FBTTH $\left.{ }_{2}\right)_{2}$ with P3HT:PC ${ }_{71} \mathrm{BM}$ and found that the best PCE of $3.71 \%$ was obtained for $\mathrm{p}$-DTS(FBTTH $)_{2}$ : $\mathrm{P} 3 \mathrm{HT}: \mathrm{PC}_{71} \mathrm{BM}(0.15: 0.85: 1)$ ternary solar cells. This PCE value was $24 \%$ higher than that of the binary system (P3HT:PC ${ }_{71} \mathrm{BM}$ ). The improvement in PCE is attributed to a combination of cascade charge transfer in the ternary system and Förster resonance energy transfer (FRET) or energy transfer process between P3HT and p-DTS $\left(\mathrm{FBTTH}_{2}\right)_{2}$, leading to the enhancement of $\mathrm{J}_{\mathrm{sc}}$ values [33]. Honda et al. reported that incorporating silicon phthalocyanine derivative (SiPc) into P3HT:PCBM increased the PCE from $2.2 \%$ to $2.7 \%$. They found that when SiPc located at the P3HT/PCBM interface can facilitate energy transfer from P3HT to SiPc molecule, yielding a higher $\mathrm{J}_{\mathrm{sc}}$ [34]. Haung et al. mixed squaraine (SQ) dyes with P3HT:PCBM. The PCE was increased from $3.27 \%$ to $4.51 \%$ because the absorption of SQ complemented absorption of P3HT and also overlapped with the photoluminescence (PL) of P3HT. Thus, an efficient FRET process can occur from P3HT to SQ, resulting in the enhancement of both $\mathrm{J}_{\mathrm{sc}}$ and FF [28]. Wang et al. employed a small diketopyrrolopyrrole based molecule, namely, DPP4T-Cz, as the third component in P3HT:PCBM solar cells. They found that a small amount of DPP4T-Cz (3.4 wt.\%) can increase the PCE to 30\%, which was attributed to the panchromatic light absorption and energy transfer from P3HT to DPP4T-Cz [35]. Baran et al. incorporate small non-fullerene acceptors, IDTBR and IDFBTR, into a P3HT matrix. The ternary blend P3HT:IDTBR:IDFBTR (1:0.7:0.3) demonstrated the highest PCE of 7.7\%. The high performance of the ternary solar cell was due to the optimal phase morphology and reduced charge recombination [36].

Recently, boron dipyrromethene or the BODIPY derivative has attracted attention for enhancing the light absorption in organic solar cells and dye-sensitized solar cells [37-41]. A donor-acceptor-donor $(\mathrm{D}-\mathrm{A}-\mathrm{D})$ triad is an attractive structure because it can increase cross-sectional absorption and $\pi$-conjugation electron delocalization [42-44]. The absorption of the donor-BODIPY-donor triad can be tuned from 500 to $800 \mathrm{~nm}$, depending on the structural modification of the BODIPY core and the donor units such as ferrocenyl, benzodithiophene, triphenylamine, and carbazole [42,45-47]. Some groups have reported the incorporation of BODIPY in ternary solar cells. For example, Min et al. synthesized two benzannulated aza-BODIPY derivatives for blending with P3HT: (6,6)-phenyl-C61-butyric acid methyl ester $\left(\mathrm{PC}_{61} \mathrm{BM}\right)$. Both could extend the absorption of the ternary blends to the near-IR region. However, only aza-BODIPY functionalized with phenyl groups could enhance the PCE from $2.64 \%$ to $2.81 \%$. This was attributed to the matching energy level that facilitate cascade charge transfer in the ternary blend [48].

According to our previous report, we synthesized BODIPY triads containing triphenylamine (TPA) and carbazole (CBZ) groups. These BODIPY triads showed an absorption maxima at $540 \mathrm{~nm}$ with moderate hole carrier mobilities [49]. Therefore, we are interested to incorporate BODIPYs triads as the second donor in Therefore, we are interested in incorporating BODIPYs triads as the second donor in P3HT:PCBM solar cell. P3HT:PCBM was chosen because P3HT is low-cost and air-processable and has good thermal stability, while PCBM, compared to non-fullerene acceptors, has shown a better photo stability under operational conditions [9,50]. In this work, TPA-BODIPY-TPA 
(BODIPY-1) and CBZ-BODIPY-CBZ (BODIPY-2) were mixed with P3HT with different weight ratios. BODIPY:P3HT donors were blended with fullerene derivative (6,6)-phenyl-C61-butyric acid methyl ester $\left(\mathrm{PC}_{61} \mathrm{BM}\right)$, an acceptor, to fabricate ternary solar cells. The photophysical properties of the blended active material were studied. The solar cell efficiency was investigated and the influence of blending BODIPY on the photovoltaic parameter, the external quantum efficiency (EQE) and the surface morphology were discussed.

\section{Materials and Methods}

\subsection{Materials}

(((3,5-Dimethyl-1H-pyrrol-2-yl)(3,5-dimethyl-2H-pyrrol-2-ylidene)methyl)methane) (difluoroborane) and 9-ethylcarbazole-3-boronic acid were purchased from Tokyo Chemical Industry Co. LTD. (Tokyo, Japan). N-Iodosuccinimide, 4-(diphenylamino)phenylboronic acid and tetrakis (triphenylphosphine) palladium $(0)\left(\mathrm{Pd}\left(\mathrm{PPh}_{3}\right)_{4}\right)$, poly-3-hexyltiophene ( $\left.\mathrm{P} 3 \mathrm{HT}\right)$ (regioregular, $99.995 \%$ ) with an average molecular weight of 54,000-75,000 $\mathrm{g} \mathrm{mol}^{-1},(6,6)$-phenyl-C61-butyric acid methyl ester $\left(\mathrm{PC}_{61} \mathrm{BM}\right)$, and indium tin oxide (ITO) coated glass substrates $\left(10 \times 10 \mathrm{~cm}^{2}, 6 \Omega / \mathrm{cm}^{2}\right)$ were purchased from Merck KGaA (Sigma Aldrich) (Darmstadt, Germany). PEDOT: PSS (PH 1000) was purchased from Ossila Ltd.(Sheffield, UK). $\mathrm{TiO}_{2}$ sol-gel was prepared by following the procedure reported by Gregory et al. [51]. Anhydrous sodium sulfate and potassium carbonate were purchased from Thermo Fisher Scientific (Thailand) Ltd. (Bangkok, Thailand). HPLC grade toluene, dichloromethane (DCM), chloroform and hexane were purchased from Fisher. Isopropanol was purchased from Carlo Erba Reagent. DI water $(\mathrm{pH} 6.2,0.8 \mu \Omega / \mathrm{cm})$ was purchased from Siam Beta (Bangkok, Thailand). Deuterated chloroform $\left(\mathrm{CDCl}_{3}\right)$ were purchased from Cambridge Isotope Laboratories. Silica gel for column chromatography was purchased from Silicycle. All chemicals were used as received.

\subsection{Synthesis}

\subsubsection{Synthesis of 2,6-diiodo-BODIPY}

(((3,5-Dimethyl-1H-pyrrol-2-yl)(3,5-dimethyl-2H-pyrrol-2-ylidene)methyl)methane) (difluoroborane), the BODIPY precursor $(0.5 \mathrm{~g}, 1.9 \mathrm{mmol})$ was dissolved in chloroform $(30 \mathrm{~mL})$ and purged for $10 \mathrm{~min}$. Afterwards, N-iodosuccinimide (NIS) $(1.1 \mathrm{~g}, 4.8 \mathrm{mmol})$ in dry DMF $(6 \mathrm{~mL})$ was added to a BODIPY solution. The reaction mixture was stirred at room temperature under $\mathrm{N}_{2}$ gas for $48 \mathrm{~h}$. Next, the solvent was removed from the crude mixture using a rotary evaporator. The crude mixture was then extracted with dichloromethane (DCM) and water. The organic layers were dried over $\mathrm{Na}_{2} \mathrm{SO}_{4}$ and concentrated by rotary evaporator. The crude mixture was purified by column chromatography over silica with DCM/hexane (5:95) as an eluent to yield 2,6-diiodo-BODIPY $(0.78 \mathrm{~g}, 80 \%) .{ }^{1} \mathrm{H}-\mathrm{NMR}\left(400 \mathrm{MHz}, \mathrm{CDCl}_{3}\right): \delta$ (ppm), $2.63\left(\mathrm{~s}, 6 \mathrm{H}, \mathrm{CH}_{3}\right), 2.61\left(\mathrm{~s}, 6 \mathrm{H}, \mathrm{CH}_{3}\right), 2.47\left(\mathrm{~s}, 3 \mathrm{H}, \mathrm{CH}_{3}\right){ }^{13} \mathrm{C}-\mathrm{NMR}\left(100 \mathrm{MHz}, \mathrm{CDCl}_{3}\right): \delta(\mathrm{ppm}) 155.06$, $142.97,141.14,132.14,85.79,29.69,19.83,19.81,17.87,16.00$.

\subsubsection{Synthesis of BODIPY-1 (TPA-BODIPY-TPA)}

2,6-Diiodo-BODIPY (0.18 g, $0.35 \mathrm{mmol}$ ) and 4-(diphenylamino)phenylboronic acid (0.25 g, $0.88 \mathrm{mmol}$ ) were dissolved in dry toluene $(20 \mathrm{~mL})$. The solution was degassed with $\mathrm{N}_{2}$ gas for $15 \mathrm{~min}$. Afterwards, $\mathrm{Pd}\left(\mathrm{PPh}_{3}\right)_{4}(0.04 \mathrm{~g}, 0.04 \mathrm{mmol})$ and $\mathrm{K}_{2} \mathrm{CO}_{3}(2 \mathrm{M})$ were added to the solution mixture. The reaction mixture was refluxed at $110{ }^{\circ} \mathrm{C}$ under nitrogen for $48 \mathrm{~h}$. After the completion of the reaction (checking by TLC), the reaction mixture was extracted with DCM and water. The organic layers were dried over $\mathrm{Na}_{2} \mathrm{SO}_{4}$ and concentrated under reduced pressure. The crude mixture was then purified by column chromatography using DCM/hexane (30:70) as the eluents to yield BODIPY-1 (TPA-BODIPY-TPA) as maroon powder. $(1.6 \mathrm{~g}, 62 \%) .{ }^{1} \mathrm{H}-\mathrm{NMR}\left(400 \mathrm{MHz}, \mathrm{CDCl}_{3}\right): \delta(\mathrm{ppm}), 7.30-7.26$ $\left(\mathrm{m}, 8 \mathrm{H}, \mathrm{CH}_{\mathrm{AR}}\right), 7.16-7.11\left(\mathrm{~m}, 12 \mathrm{H}, \mathrm{CH}_{\mathrm{AR}}\right) 7.08-7.02(\mathrm{~m}, 8 \mathrm{H}, \mathrm{CHAR}) 2.71\left(\mathrm{~s}, 3 \mathrm{H}, \mathrm{CH}_{3}\right), 2.53\left(\mathrm{~s}, 6 \mathrm{H}, \mathrm{CH}_{3}\right)$, 
$2.38\left(\mathrm{~s}, 6 \mathrm{H}, \mathrm{CH}_{3}\right){ }^{13} \mathrm{C}-\mathrm{NMR}\left(100 \mathrm{MHz}, \mathrm{CDCl}_{3}\right): \delta(\mathrm{ppm}), 147.68,146.79,131.10,129.32,124.58,123.08$, $123.04,17.30,15.65,13.40$.

\subsubsection{BODIPY-2 (CBZ-BODIPY-CBZ)}

2,6-Diiodo-BODIPY ( $0.20 \mathrm{~g}, 0.39 \mathrm{mmol})$ and 9-ethylcarbazole-3-boronic acid $(0.20 \mathrm{~g}, 1.1 \mathrm{mmol})$ were dissolved in dry toluene $(20 \mathrm{~mL})$. The solution was purged with $\mathrm{N}_{2}$ gas for $15 \mathrm{~min}$. Next, $\mathrm{Pd}\left(\mathrm{PPh}_{3}\right)_{4}$ $(0.04 \mathrm{~g}, 0.04 \mathrm{mmol})$ and $\mathrm{K}_{2} \mathrm{CO}_{3}(2 \mathrm{M})$ were added. After that, the reaction mixture was refluxed at $110^{\circ} \mathrm{C}$ under nitrogen for $48 \mathrm{~h}$. The crude mixture was then extracted with DCM and water. The organic layers were dried over $\mathrm{Na}_{2} \mathrm{SO}_{4}$ and concentrated using a rotary evaporator. The crude product was purified by column chromatography using DCM/hexane (30:70) as the eluents to yield BODIPY-2 (CBZ-BODIPY-CBZ) as a red-wine colored powder $(0.15 \mathrm{~g}, 59 \%) .{ }^{1} \mathrm{H}-\mathrm{NMR}\left(400 \mathrm{MHz}, \mathrm{CDCl}_{3}\right): \delta(\mathrm{ppm})$, $12\left(\mathrm{~s}, 1 \mathrm{H}, \mathrm{CH}_{\mathrm{AR}}\right), 8.10\left(\mathrm{~s}, 1 \mathrm{H}, \mathrm{CH}_{\mathrm{AR}}\right), 7.95\left(\mathrm{~d}, 1 \mathrm{H}, \mathrm{CH}_{\mathrm{AR}}\right), 7.49-7.45\left(\mathrm{~m}, 6 \mathrm{H}, \mathrm{CH}_{\mathrm{AR}}\right), 7.34-7.32(\mathrm{~d}, 2 \mathrm{H}$, $\left.\mathrm{CH}_{\mathrm{AR}}\right)$ 7.27-7.23 (m, 3H, CH $\left.\mathrm{AR}\right), 4.45\left(\mathrm{~m}, 4 \mathrm{H}, \mathrm{CH}_{2}\right) 2.76\left(\mathrm{~s}, 3 \mathrm{H}, \mathrm{CH}_{3}\right), 2.56\left(\mathrm{~s}, 6 \mathrm{H}, \mathrm{CH}_{3}\right), 2.41(\mathrm{~s}, 6 \mathrm{H}$, $\left.\mathrm{CH}_{3}\right), 1.51\left(\mathrm{t}, 3 \mathrm{H}, \mathrm{CH}_{3}\right) .{ }^{13} \mathrm{C}-\mathrm{NMR}\left(100 \mathrm{MHz}, \mathrm{CDCl}_{3}\right): \delta(\mathrm{ppm}), 152.70,141.23,140.26,139.27,137.05$ $134.43,132.23,132.21,128.13,125.87,124.23,123.05,122.78,122.21$. 120.48, 118.95, 118.97, 108.59, 108.32, $37.68,17.26,15.68,13.92,13.44$.

\subsection{Solar Cell Fabrication}

The patterned ITO substrates $(25 \mathrm{~mm} \times 20 \mathrm{~mm})$ were cleaned with commercial detergent, Alconox solution (10 wt.\%), isopropanol, and DI water under sonication for $30 \mathrm{~min}$, respectively. Then, the ITO substrates were treated with UV light (UV-LED, $365 \mathrm{~nm}$, Larson Electronics, Kemp, TX, USA) for $30 \mathrm{~min}$ before use. The $80 \mu \mathrm{L}$ of filtered PEDOT: PSS was deposited onto the ITO substrates by using the spin coating technique at $3000 \mathrm{rpm}$ for $40 \mathrm{~s}$. After annealing at $140{ }^{\circ} \mathrm{C}$ for $30 \mathrm{~min}$ in air, the substrates were quickly transferred to a glove box filled with nitrogen gas (RH $\sim 10 \%$ ). The $50 \mu \mathrm{L}$ of P3HT (and/or BODIPY-1, BODIPY-2): PCBM (1:1 by wt.) $(20 \mathrm{mg} / \mathrm{mL}$ in chloroform) solution was spin coated onto the PEDOT: PSS layer at $2500 \mathrm{rpm}$ for $30 \mathrm{~s}$. Then, the $60 \mu \mathrm{L}$ of $\mathrm{TiO}_{2}$ solution was coated on active layer at $4000 \mathrm{rpm}$ for $30 \mathrm{~s}$. The coated substrates were annealed at $110^{\circ} \mathrm{C}$ for $10 \mathrm{~min}$ and then transferred to thermal evaporator to deposit the aluminum cathode (film thickness $\sim 90-110 \mathrm{~nm}$ ). The active area of the device was $4 \mathrm{~mm}^{2}$.

\subsection{Instrumentations}

${ }^{1} \mathrm{H}-\mathrm{NMR}$ spectra were recorded on a $400 \mathrm{MHz}$ NMR spectrometer (Ascend 400, Bruker BioSpin $\mathrm{GmBH}$, Rheinstetten, Germany) and were reported in ppm using the residual proton resonance of the solvent as the internal standard $\left(\mathrm{CDCl}_{3}\right.$ at $\left.7.26 \mathrm{ppm}\right) .{ }^{13} \mathrm{C}-\mathrm{NMR}$ spectra were proton decoupled and recorded on a $100 \mathrm{MHz}$ Bruker spectrometer using the carbon signal of the deuterated solvent as the internal standard. Thermogravimetric analysis (TGA) of BODIPY-1 and BODIPY-2 were measured using a thermogravimetric analyzer (Diamond TA/Q50, TA instruments, New Castle, DE, USA). The absorption spectra of BODIPY and P3HT solution were recorded on a Thermo Scientific UV-Genesys $10 \mathrm{~s}$ spectrophotometer. The solid state absorption spectra of BODIPY and P3HT and blended films were recorded on a UV-Vis-NIR spectrophotometer (SolidSpec-3700, Shimadzu, Kyoto, Japan). Fluorescence spectra were recorded on a PerkinElmer LS 55 fluorescence spectrometer. Electrochemical Impedance spectroscopy (EIS) (PGSTAT302, Metrohm Autolab B. V., Utrecht, the Natherlands) was conducted on an AUTOLAB. The surface morphology of thin films were characterized using an atomic force microscope (AFM) (NaioAFM, Nanosurf, Liestal, Switzerland). Contact angles were measured by a static optical contact angle meter (KINO SL150E). The current density-voltage (J-V) curves were measured using a Keithley 2400 source-measurement unit and a Newport 94011A solar simulator. The external quantum efficiency (EQE) measurement was performed on a Newport Oriel QEPVSI-b under the irradiation of a Xenon lamp equipped with a monochromator controlled via USB connection through TracQ software (version 6.7, Newport Corporation, Irvine, CA, USA). 


\section{Results and Discussion}

\subsection{Synthesis}

Our target BODIPY compounds, TPA-BODIPY-TPA (BODIPY-1) and CBZ-BODIPY-CBZ (BODIPY-2) (Figure 1), were synthesized following our previous report [49]. The chemical structures were confirmed using ${ }^{1} \mathrm{H}-\mathrm{NMR}$ and ${ }^{13} \mathrm{C}-\mathrm{NMR}$, respectively (see Supplementary Materials, Figures S1-S6). Thermal gravimetric analysis was carried out to investigate the thermal degradation. The $2.5 \%$ decomposition temperatures $\left(\mathrm{T}_{\mathrm{d}}\right)$ of BODIPY-1 and BODIPY-2 were $200{ }^{\circ} \mathrm{C}$ and $225^{\circ} \mathrm{C}$ (Figure S7), respectively, indicating that they are stable for use as the active layers of solar cells [52].

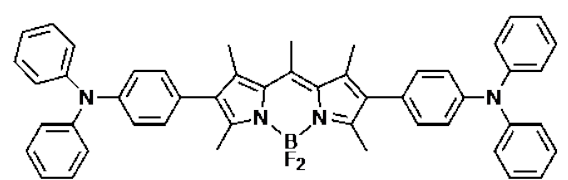

BODIPY-1<smiles>CCCCCc1ccc(C)s1</smiles>

P3HT

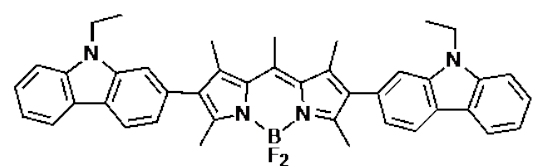

BODIPY-2

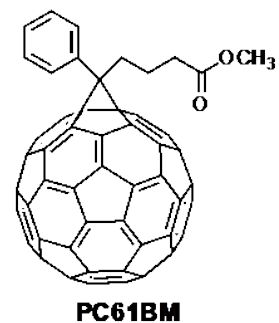

Figure 1. The corresponding chemical structures of boron dipyrromethene-1 (BODIPY-1), BODIPY-2, poly-3-hexyl thiophene (P3HT), and (6,6)-phenyl-C61-butyric acid methyl ester ( $\left.\mathrm{PC}_{61} \mathrm{BM}\right)$ for use in ternary solar cells.

\subsection{Optical Characterizations}

The absorption spectra of BODIPY-1 and BODIPY-2 exhibited narrow absorption with absorption maxima at 537 and $532 \mathrm{~nm}$, and high extinction coefficients of $\sim 3 \times 10^{4}$ and $8 \times 10^{4} \mathrm{M}^{-1} \mathrm{~cm}^{-1}$, respectively (Figure 2a). P3HT showed a broader spectrum, with absorption maxima at $453 \mathrm{~nm}$, while the solid-state absorption of the P3HT was red-shifted by of $\sim 50 \mathrm{~nm}$ with respect to that of the P3HT in solution (Figure 2b). The absorption spectra of BODIPY blended P3HT films are a combination of the individual spectra BODIPY and P3HT, indicating cooperative of light harvesting.
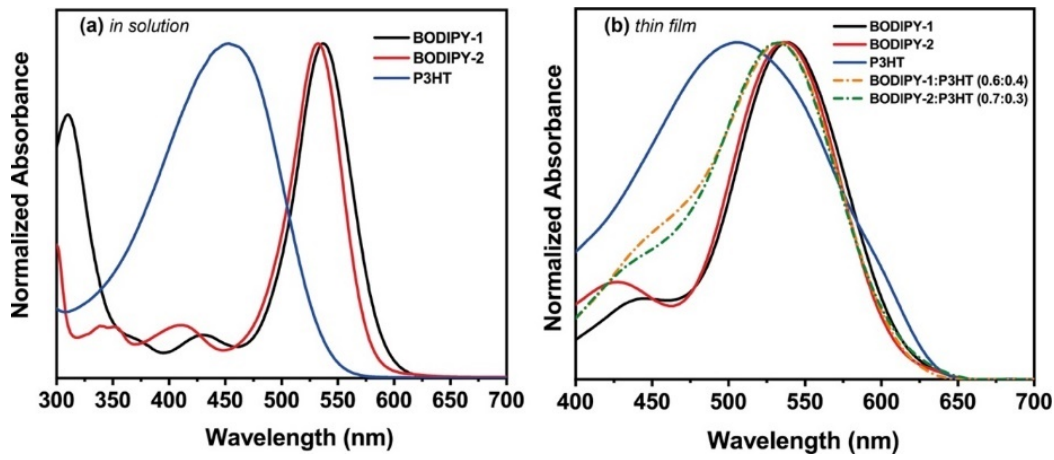

Figure 2. (a) Normalized absorption spectra of BODIPY-1, BODIPY-2 and P3HT in chloroform. (b) Normalized absorption spectra of BODIPY-1, BODIPY-2, P3HT, BODIPY-1:P3HT (0.6:0.4) and BODIPY-2:P3HT (0.7:0.3) films. 


\subsection{Photovoltaic Performance}

Binary and ternary solar cells were fabricated in a regular architecture (ITO/PEDOT:PSS/ BODIPY:P3HT:PC 61 BM/TiO $/ \mathrm{Al})$ under the same conditions. The current-voltage $(\mathrm{J}-\mathrm{V})$ characteristic curves of solar cells are presented in Figure 3c,d and the photovoltaic performance parameters including short circuit current density $\left(\mathrm{J}_{\mathrm{SC}}\right)$, open circuit voltage $\left(\mathrm{V}_{\mathrm{OC}}\right)$, fill factor $(\mathrm{FF})$ and power conversion efficiency (PCE) are summarized in Table 1. The control device fabricated from P3HT:PCBM provided a PCE of $2.22 \%$, with a $\mathrm{J}_{\mathrm{SC}}$ of $6.77 \mathrm{~mA} / \mathrm{cm}^{2}$, a $\mathrm{V}_{\mathrm{oc}}$ of $0.63 \mathrm{~V}$, and an FF of 0.52 . Binary solar devices fabricated from BODIPY-1:PCBM and BODIPY-2:PCBM have PCEs of $1.85 \%$ and 1.92\%, respectively. The lower performance of BODIPY:PCBM solar cells is attributed to the narrow absorption properties of BODIPY, resulting in lower $\mathrm{J}_{\mathrm{sc}}$ values. The photovoltaic performance of ternary solar cells were optimized by varying weight ratio of P3HT and BOIDPY. We found that incorporating a lower quantity of BODIPY in P3HT:PCBM led to a reduction in the performance of devices (see Table S1). Interestingly, increasing BODIPY concentration in P3HT:PCBM significantly enhanced $\mathrm{J}_{\mathrm{Sc}}$ values, leading to the improvement of device efficiency as compared to those of P3HT:PCBM or BODIPY:PCBM binary solar cells (Table 1 and Figure 3e). Ternary solar cells containing BODIPY-1:P3HT (0.6:0.4) exhibited the highest PCE (3.43\%) due to a large enhancement in $\mathrm{J}_{\mathrm{sc}}\left(9.45 \mathrm{~mA} / \mathrm{cm}^{2}\right)$ and an increase in FF (0.54). The efficiency was raised by $55 \%$ as compared to the control P3HT device. Incorporating BODIPY-2 with P3HT also improved the solar cell performance. The device fabricated with BODIPY-2:P3HT (0.7:0.3) provided a PCE of $3.20 \%$, with the highest $\mathrm{J}_{\mathrm{sc}}$ value of $9.96 \mathrm{~mA} / \mathrm{cm}^{2}$. However, the $\mathrm{V}_{\mathrm{oc}}$ values of the champion devices are slightly increased as compared to the P3HT device. In general, the $\mathrm{V}_{\mathrm{OC}}$ of the P3HT:PCBM solar cells is limited by a high voltage loss $\left(\Delta \mathrm{E}_{\text {loss }}\right)$, in a range of $1.10-1.35 \mathrm{eV}[11,53-56]$. This loss is caused by three factors: (i) the radiative recombination from the absorption above the bandgap $(\sim 0.30 \mathrm{eV})$, (ii) an additional radiative recombination from the absorption below the bandgap $(>0.6 \mathrm{eV})$, and (iii) the non-radiative recombination $(>0.3 \mathrm{eV})$ [11,53-56]. In this work, P3HT:PCBM binary solar cell has a voltage loss of $1.26 \mathrm{eV}$. Whereas, the voltages loss values of BODIPY-1:P3HT (0.6:0.4) and BODIPY-2:P3HT (0.7:0.3) ternary solar cells are $1.12 \mathrm{eV}$ and $1.10 \mathrm{eV}$, respectively. It should be noted that PCE of champion cells are higher than those of reported small BODIPY molecule used in ternary solar cells [48,57]. This suggested that our BODIPY triads and P3HT are a suitable combination to improve the efficiency of ternary solar cells.

Table 1. Performance parameters of ternary solar cells with BODIPY:P3HT:PCBM.

\begin{tabular}{cccccc}
\hline Devices & $\begin{array}{c}\text { Donor } \\
\text { Concentration } \\
\mathbf{a}(\mathbf{b y} \text { wt. })\end{array}$ & $\mathbf{J}_{\mathbf{s c}}\left(\mathbf{m A} / \mathbf{c m}^{2}\right)$ & $\mathbf{V}_{\mathbf{o c}}(\mathbf{V})$ & FF & $\begin{array}{c}\text { PCE (\%) } \\
\text { (Best) (Average) }\end{array}$ \\
\hline 1 & P3HT & $6.77 \pm 0.36$ & $0.63 \pm 0.02$ & $51.98 \pm 0.96$ & $2.48,2.22 \pm 0.16$ \\
\hline 2 & BODIPY-1 & $5.73 \pm 0.22$ & $0.63 \pm 0.04$ & $50.91 \pm 0.92$ & $2.00,1.85 \pm 0.17$ \\
\hline 3 & BODIPY-2 & $5.81 \pm 0.49$ & $0.63 \pm 0.03$ & $52.01 \pm 0.85$ & $2.29,1.92 \pm 0.19$ \\
\hline 4 & $\begin{array}{c}\text { BODIPY-1:P3HT } \\
(0.8: 0.2)\end{array}$ & $6.68 \pm 0.31$ & $0.62 \pm 0.01$ & $53.78 \pm 0.56$ & $2.33,2.24 \pm 0.10$ \\
\hline 5 & $\begin{array}{c}\text { BODIPY-1:P3HT } \\
(0.7: 0.3)\end{array}$ & $7.82 \pm 0.12$ & $0.65 \pm 0.04$ & $53.70 \pm 0.55$ & $2.90,2.71 \pm 0.20$ \\
\hline 6 & $\begin{array}{c}\text { BODIPY-1:P3HT } \\
(0.6: 0.4)\end{array}$ & $9.45 \pm 0.33$ & $0.67 \pm 0.02$ & $54.00 \pm 0.48$ & $3.71,3.43 \pm 0.15$ \\
\hline 7 & $\begin{array}{c}\text { BODIPY-2:P3HT } \\
(0.8: 0.2)\end{array}$ & $6.54 \pm 0.35$ & $0.64 \pm 0.06$ & $50.81 \pm 1.15$ & $2.23,2.11 \pm 0.17$ \\
\hline 8 & $\begin{array}{c}\text { BODIPY-2:P3HT } \\
(0.7: 0.3)\end{array}$ & $9.96 \pm 0.16$ & $0.62 \pm 0.04$ & $51.74 \pm 1.32$ & $3.38,3.20 \pm 0.25$ \\
\hline 9 & $\begin{array}{c}\text { BODIPY-2:P3HT } \\
(0.6: 0.4)\end{array}$ & $7.75 \pm 0.36$ & $0.66 \pm 0.05$ & $51.71 \pm 1.68$ & $2.99,2.63 \pm 0.26$ \\
\hline
\end{tabular}

a All donors were blended with PCBM at a weight ratio of 1:1. The average parameters were obtained from 10 devices. 
(a)

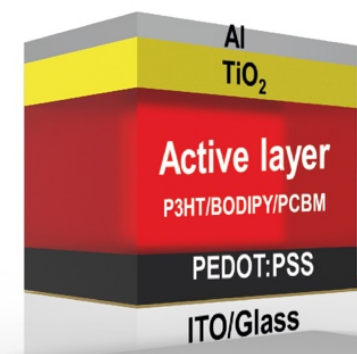

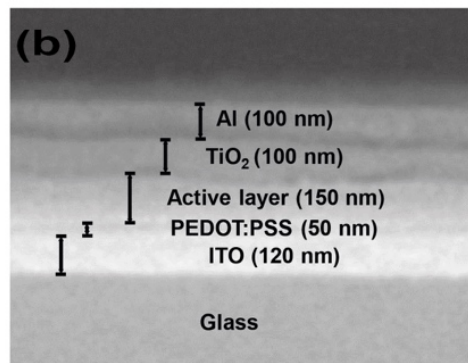
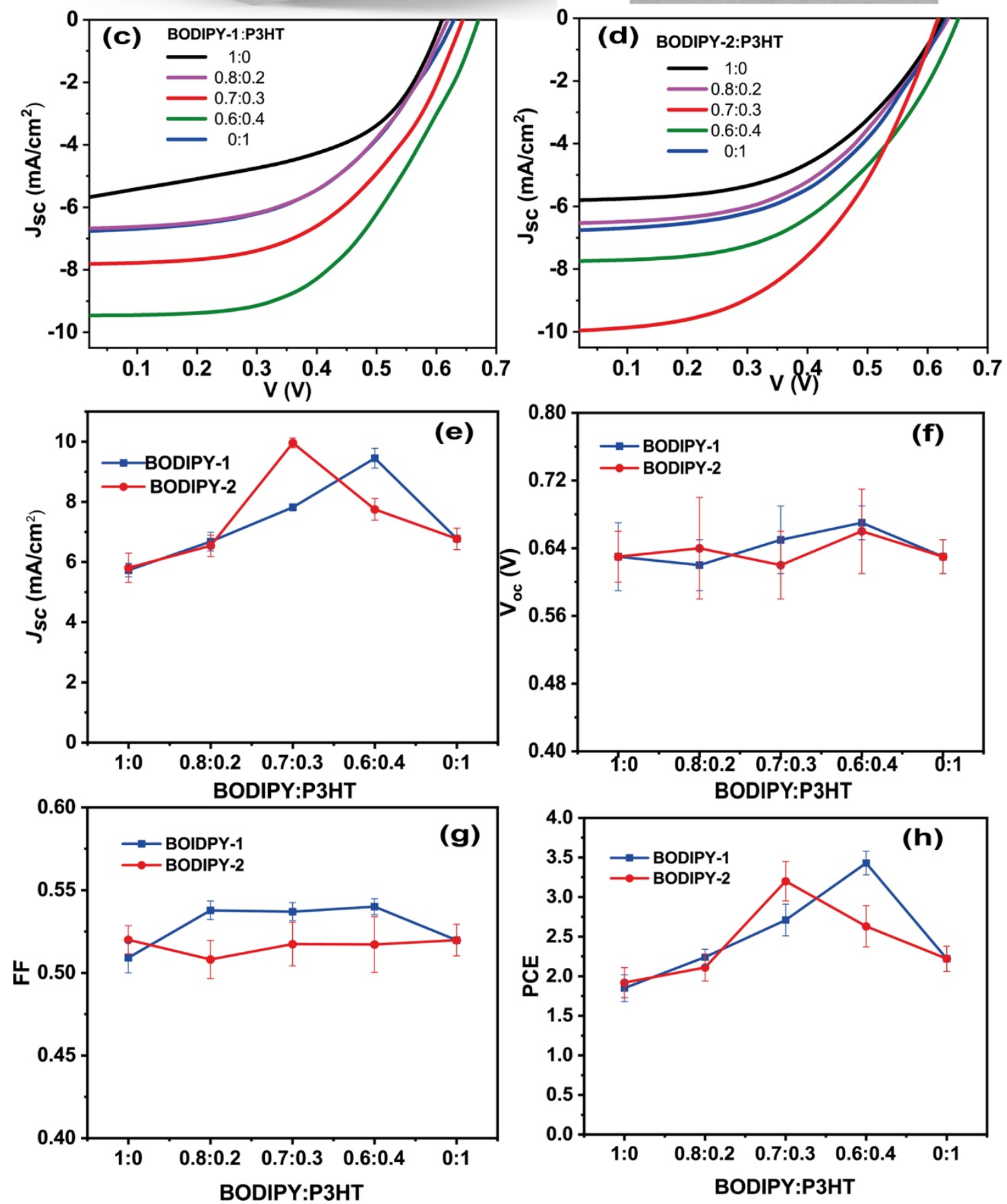

Figure 3. (a) Device architecture, (b) SEM cross-section of a solar cell, (c,d) J-V curve of BODIPY-1:P3HT:PCBM and BODIPY-2:P3HT:PCBM ternary solar cells, and (e-h) Photovoltaic parameters $\left(\mathrm{J}_{\mathrm{sc}}, \mathrm{V}_{\mathrm{Oc}}, \mathrm{FF}\right.$ and PCE) plotted against the weight ratio of BODIPY and P3HT. 


\subsection{External Quantum Efficiency (EQE)}

The EQE spectra of binary solar cell and ternary solar cell are depicted in Figure 4. The EQE of P3HT device was 35\% at $500 \mathrm{~nm}$, while the EQE of BODIPY-1 and BOIDPY-2 devices were $20 \%$ at wavelengths of 400 and $550 \mathrm{~nm}$. For the ternary blend system, the EQE of the ternary solar cells were higher than those of BODIPY and P3HT binary solar cells. The EQE spectra for BODIPY-1:P3HT (0.6:0.4) and BODIPY-2:P3HT (0.7:0.3) illustrated that EQE in BODIPY and P3HT absorption were increased up to $40 \%$ and covered in a broader range from 350 to $700 \mathrm{~nm}$. In addition, the trend in EQE spectra and increase in the photocurrent generation are in good agreement.

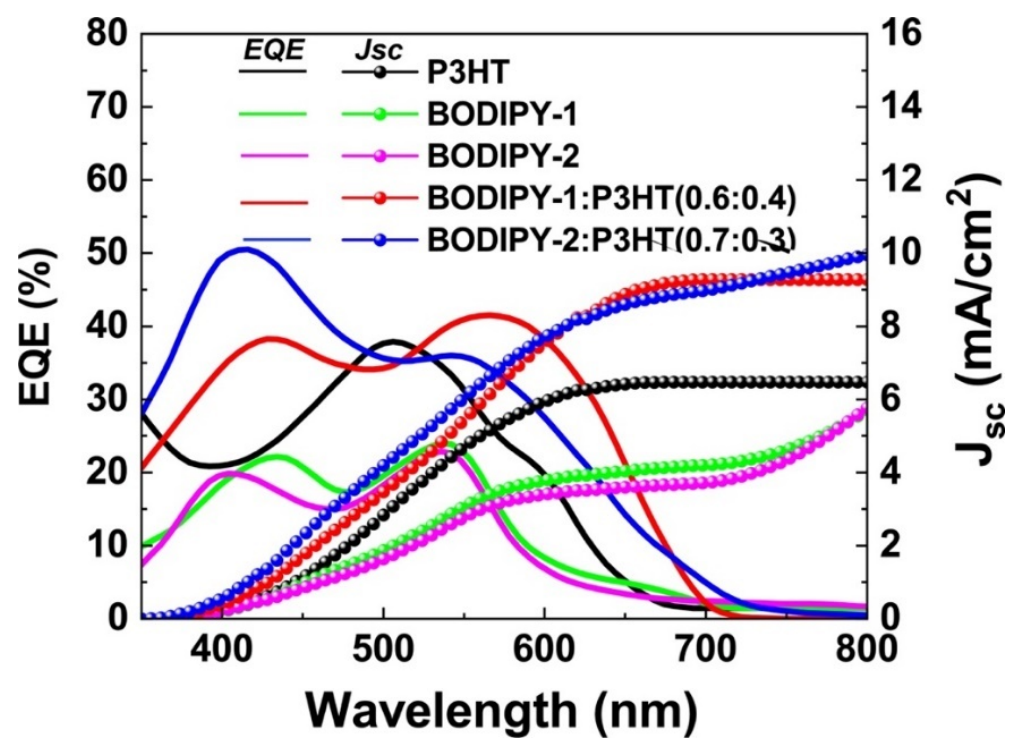

Figure 4. The external quantum efficiency (EQE) spectra of P3HT, BODIPY-1, and BODIPY-2 binary solar cells and BODIPY-1:P3HT(0.6:0.4) and BODIPY-2:P3HT (0.7:0.3) ternary solar cells.

\subsection{Impedance Analysis}

It is well known that the suppression of dark saturation current density $\left(\mathrm{J}_{0}\right)$ can increase the $\mathrm{V}_{\mathrm{oc}}$ value of organic photovoltaics (OPVs) as a result of the reduction in charge recombination at the interface between the active layer and the anode/cathode layer [58,59]. Electrochemical impedance spectroscopy (EIS) was used to investigate the charge recombination process, which is directly related to the $\mathrm{V}_{\mathrm{oc}}$ in OPV devices. EIS was performed over a frequency range from $0.01 \mathrm{~Hz}$ to $1 \mathrm{MHz}$ at an amplitude of $10 \mathrm{mV}$. The EIS spectra were fitted by using an equivalent circuit model, as shown in the inset of Figure 5. $R_{\mathrm{s}}, \mathrm{R}_{\mathrm{rec}}$, and CPE represented the series resistance, the charge recombination resistance, and the constant phased element representing the chemical capacitance, respectively $[60,61]$. Figure 5 showed Nyquist plots of binary solar cells and ternary solar cells under 1 sun simulation. The semicircle represented the charge recombination resistance $\left(R_{\text {rec }}\right)$ of the solar cell. It was found that the radius of the semicircle of the Nyquist plot was increased when BODIPY triads were applied in the ternary system. This suggests that charge recombination was significantly suppressed, resulting in the increase in $\mathrm{V}_{\mathrm{oc}}$ that was observed in champion devices. In addition, we found that the $\mathrm{P}$ value of CPE, simulated by an EIS software analyzer (Table S2, increased from 0.70 (P3HT device) to 0.90 (BODIPY-1:P3HT (0.6:0.4) device). This P value of the champion device is close to the $P$-value of an ideal capacitor $(P=1)$ without grain boundary and/or defect [59]. Since voltage loss values of BODIPY-1:P3HT and BODIPY-2:P3HT devices were similar (1.1 eV), a higher PCE of BODIPY-1:P3HT could be due to efficient charge transport in the active layer. This suggests that the active layer film formed by the ternary blended system has low charge trapping sites, originating from defects such as pin-holes or the grain boundaries of the film, and corresponds to the atomic force microscope (AFM) 
results), showing that the quality of the active film was higher and had greater homogeneity when BODIPY triads were applied in the active layer.

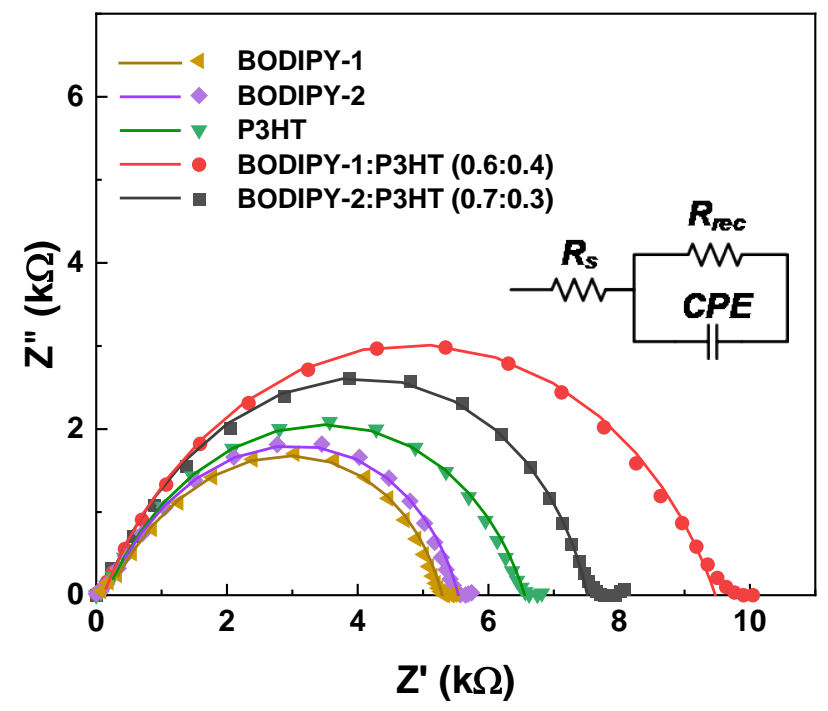

Figure 5. The electrochemical impedance spectroscopy (EIS) spectra of BODIPY-1, BODIPY-2, and P3HT binary solar cells and BODIPY-1:P3HT (0.6:0.4) and BODIPY-2:P3HT (0.7:0.3) ternary solar cells under 1 sun simulation and an open circuit condition.

\subsection{Morphology Study}

Morphology of the photoactive layer is known as a critical factor that optimizes photon/electron conversion efficiency of ternary solar cells [62-65]. To determine surface roughness and phase behavior of the blended active layer, AFM has been investigated in tapping mode (Figure 6a-e). For an accurate comparison, all films were prepared with the same conditions for solar cell device fabrication. It is clearly seen that BODIPY-1:PCBM and BODIPY-2:PCBM films showed some void (pin-holes) and microphase separation (Figure 6a,b). The surface roughness of BODIPY blended with P3HT:PCBM exhibited lower root mean square of average height (RMS) values compared to those of the binary blends (Figure 6d,e). This indicated that blending BODIPY and P3HT yields a flatter and smoother surface. The RMS values of BODIPY-1 blended P3HT:PCBM and BODIPY-2 blended P3HT:PCBM were $0.94 \mathrm{~nm}$ and $1.61 \mathrm{~nm}$, respectively. It should be noted that the champion device, BODIPY-1:P3HT:PCBM (0.7:0.3:1) developed a more homogeneous film with an improved morphology over the binary counterpart device. This could result in more efficient charge transport at the interfacial of the donor/acceptor area and enhance the PCE [59,66-68].

Next, the BODIPY distribution in the ternary blend film was investigated using contact angle measurements of pure water [35,69]. The contact angles of BODIPY-1, BODIPY-2, P3HT, and PCBM were $93.6^{\circ}, 83.4^{\circ}, 95.3^{\circ}$, and $89.9^{\circ}$ which led to estimate their surface energy $(\gamma)$ values of $26.7,32.4$, 24.8, and $29.9 \mathrm{~mJ} / \mathrm{m}^{2}$, respectively [70-72]. The location of BODIPY in the P3HT:PCBM matrix can be estimated in terms of the wetting coefficient $(\omega)$ using surface energy and Neumann's and Young's equations [69-71,73]. According to the published literature [35,61,69,74], if $\omega>1$, BODIPY will be located in the P3HT domain. If $-1<\omega<1$, BODIPY will be located at the interface of P3HT and PCBM. If $\omega<-1$, BODIPY will be located in the PCBM domain. We found that the $\omega$ value of BODIPY-1 was 0.25, which indicates that BODIPY-1 molecules preferentially locate at the P3HT/PCBM interface. The $\omega$ value of BODIPY-2 was -1.96 , which suggests that BODIPY-2 molecules are likely to be located in the PCBM domain. 

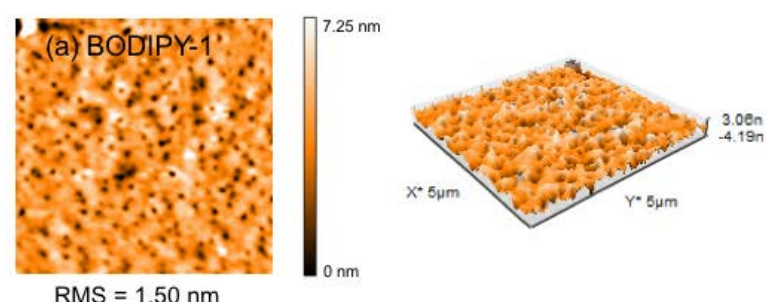

RMS $=1.50 \mathrm{~nm}$
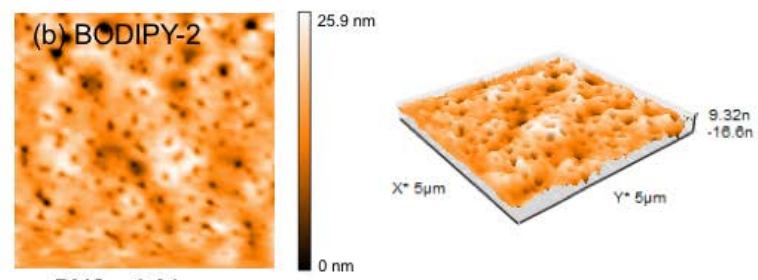

$\mathrm{RMS}=3.81 \mathrm{~nm}$
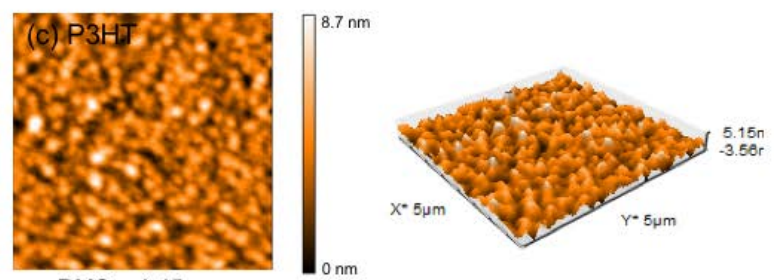

$\mathrm{RMS}=1.45 \mathrm{~nm}$
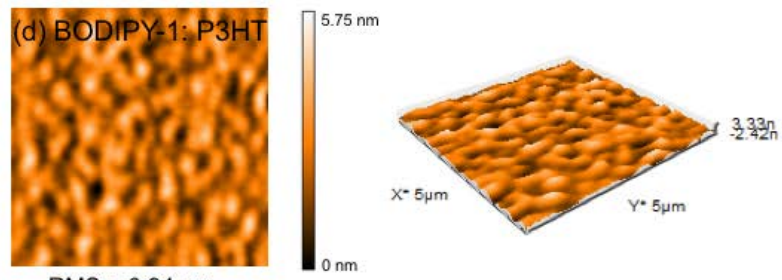

$\mathrm{RMS}=0.94 \mathrm{~nm}$
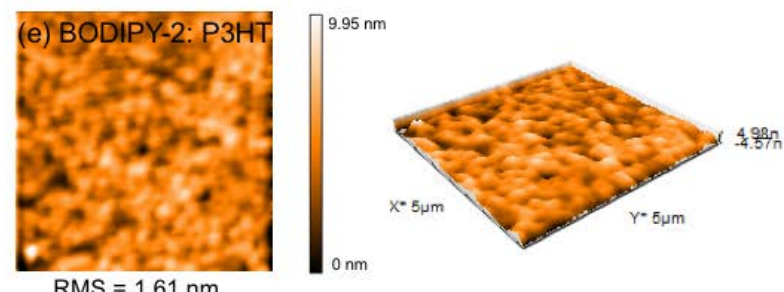

$\mathrm{RMS}=1.61 \mathrm{~nm}$

Figure 6. Tapping-mode atomic force microscope (AFM) images $(5 \mu \mathrm{m} \times 5 \mu \mathrm{m})$ : (a) BODIPY-1:PCBM (1:1) film, (b) BODIPY-2:P3HT (1:1) film, (c) P3HT:PCBM (1:1) film, (d) BODIPY-1:P3HT:PCBM (0.6:0.4:1) film, and (e) BODIPY-2:P3HT:PCBM (0.7:0.3:1) film.

\subsection{Proposed Operating Mechanism}

There are four fundamental operating models in ternary solar cells: the charge transfer, the energy transfer, the parallel-linkage, and the alloy model [17-19,23,26]. Here, we discussed a possible operating mechanism of BODIPY:P3HT:PCBM that enhance $\mathrm{J}_{\mathrm{sc}}$. Figure 7 presents the energy diagram of donor and acceptors. The HOMO and LUMO energy levels of BODIPY-1 and BODIPY-2 were estimated from our previous study [49]. The HOMO and LUMO offset $(\Delta \mathrm{E})$ values between P3HT and BODIPY are about $\sim 0.1-0.2 \mathrm{eV}$, which are energetically feasible in term of driving the cascade charge transfer from P3HT to BODIPY and from BODIPY to PCBM $[19,20]$. Since P3HT can act as both a charge donor and an energy donor [28,75], we also investigate energy transfer process using a photoluminescence (PL) study. The PL spectra of blending P3HT and BODIPY revealed that P3HT emission can be quenched by a high BODIPY content (Figure 8). This implies that an energy transfer from P3HT to BODIPY was also presented. The energy transfer from P3HT to BODIPY molecules is likely favorable due to the substantial overlapping of the P3HT emission spectrum and the BODIPY absorption, as shown in the 
inset of Figure 8 . Therefore, the boosted $\mathrm{J}_{\mathrm{sc}}$ is attributed to cascade charge transfer and energy transfer and to the favorable morphology of the ternary blend.
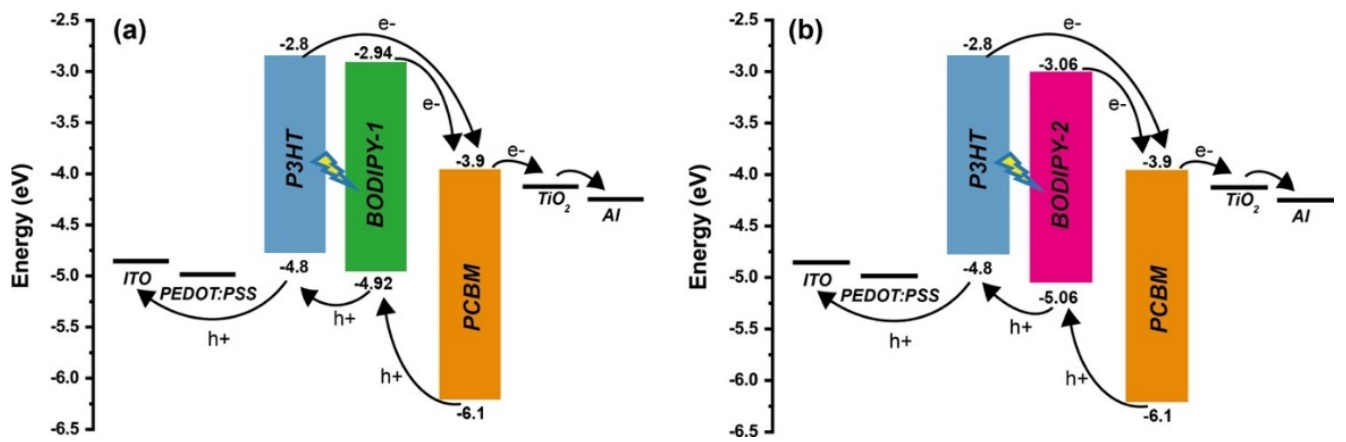

Figure 7. Energy alignment diagram of active material in ternary solar cells. (a) BODIPY-1:P3HT:PCBM and (b) BODIPY-2:P3HT:PCBM.
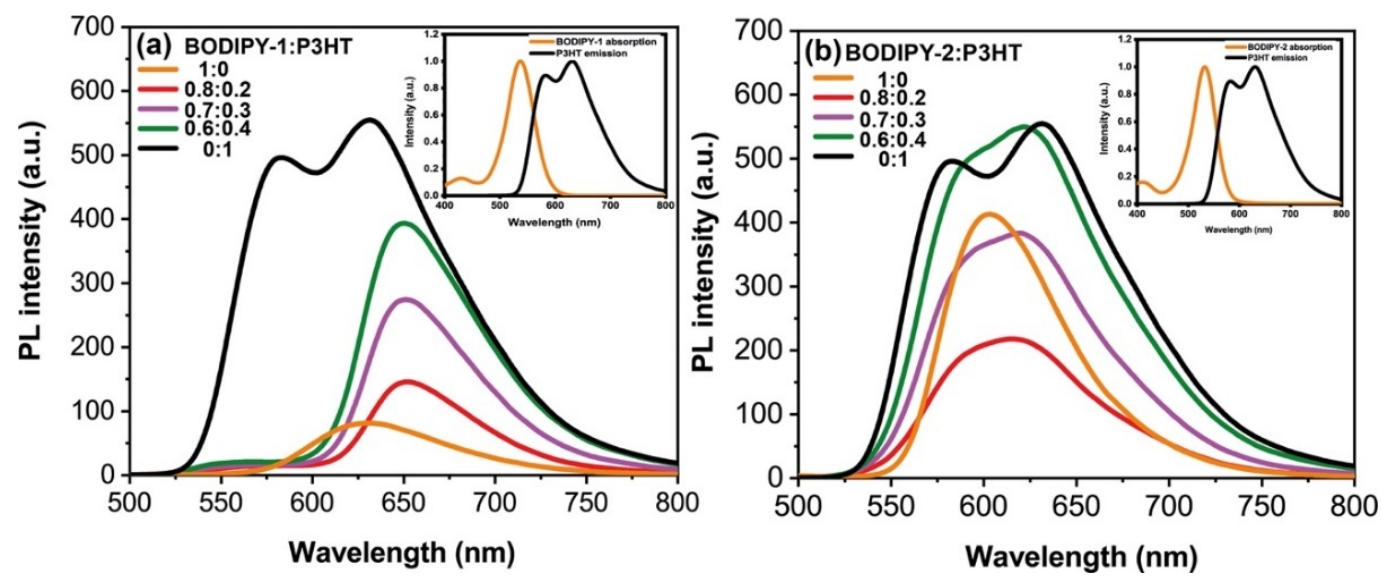

Figure 8. PL spectra of (a) P3HT/BODIPY-1 co-solution in chloroform and (b) P3HT/BODIPY-2 co-solution in chloroform. All samples were excited at $450 \mathrm{~nm}$. Inset: absorption spectrum of BODIPY (orange line) and emission spectrum of P3HT (black line).

\section{Conclusions}

In summary, we demonstrated a 55\% enhancement in PCE in ternary solar cells (BODIPY-1:P3HT:PCBM), reaching 3.43\%. The improvement in PCE is attributed to efficient charge transfer, and a smooth surface in the ternary blend that facilitates exciton dissociation and charge transportation. This finding suggests that BODIPY-1 and BODIPY-2 are suitable small molecules for improving the efficiency of the P3HT:PCBM system.

Supplementary Materials: The following are available online at http://www.mdpi.com/1996-1944/13/12/2723/s1, Figure S1: ${ }^{1} \mathrm{H}-\mathrm{NMR}$ of 2,6-diiodo-BODIPY, Figure S2: ${ }^{13} \mathrm{C}-\mathrm{NMR}$ of 2,6-diiodo-BODIPY, Figure S3: ${ }^{1} \mathrm{H}-\mathrm{NMR}$ of TPA-BODIPY-TPA (BODIPY-1), Figure S4: ${ }^{13} \mathrm{C}-\mathrm{NMR}$ of TPA-BODIPY-TPA (BODIPY-1), Figure S5: ${ }^{1} \mathrm{H}-\mathrm{NMR}$ of CBZ-BODIPY-CBZ (BODIPY-2), Figure S6: ${ }^{13}$ C-NMR of CBZ-BODIPY-CBZ, Figure S7: TGA of BODIPY-1 and BODIPY-2, Table S1: Performance parameters of ternary solar cells with BODIPY:P3HT:PCBM (P3HT concentration was higher than BODIPY), Table S2: Parameters fitted from the Nyquist plot of binary solar cells and ternary solar cells. Table S3: Contact Angle measurement of P3HT, BODIPY-1, BODIPY-2 and PCBM,

Author Contributions: Conceptualization, S.W.; methodology, S.W. and W.S.; validation, S.W. and W.S.; formal analysis, S.W. and W.S.; investigation, S.W. and W.S.; resources, S.W., P.K. and J.W.; data curation, S.W., and W.S.; writing-original draft preparation, S.W, and W.S.; writing-review and editing, S.W., P.K., and J.W., visualization, S.W. and W.S; super vision, S.W.; project administration, S.W.; funding acquisition, S.W., P.K., and J.W. All authors have read and agreed to the published version of the manuscript.

Funding: This research was funded by the Coordinating Center for Thai Government Science and Technology Scholarship Students, National Science and Technology Development Agency, Thailand, through the "Young 
Scientist Researcher Grant" This work was partially supported by King Mongkut's University of Technology Thonburi through the "KMUTT 55th Anniversary Commemorative Fund" and NANOTEC grant number P1952316.

Acknowledgments: The authors gratefully acknowledge Sankaran Thayumanavan, University of Massachusetts Amherst, for providing access to a fluorescence spectrometer instrument and Teera Butburee for providing access to an impedance spectroscopy measurement.

Conflicts of Interest: The authors declare no conflict of interest.

\section{References}

1. Dou, L.; Liu, Y.; Hong, Z.; Li, G.; Yang, Y. Low-Bandgap Near-IR Conjugated Polymers/Molecules for Organic Electronics. Chem. Rev. 2015, 115, 12633-12665. [CrossRef] [PubMed]

2. He, Z.; Zhong, C.; Su, S.; Xu, M.; Wu, H.; Cao, Y. Enhanced power-conversion efficiency in polymer solar cells using an inverted device structure. Nat. Photonics 2012, 6, 591-595. [CrossRef]

3. Green, M.A.; Emery, K.; Hishikawa, Y.; Warta, W.; Dunlop, E.D. Solar cell efficiency tables (version 39). Prog. Photovolt. Res. Appl. 2011, 20, 12-20. [CrossRef]

4. Liu, Q.; Toudert, J.; Li, T.; Kramarenko, M.; Martínez-Denegri, G.; Ciammaruchi, L.; Zhan, X.; Martorell, J. Inverse Optical Cavity Design for Ultrabroadband Light Absorption Beyond the Conventional Limit in Low-Bandgap Nonfullerene Acceptor-Based Solar Cells. Adv. Energy Mater. 2019, 9. [CrossRef]

5. Sun, J.; Ma, X.; Zhang, Z.; Yu, J.; Zhou, J.; Yin, X.; Yang, L.; Geng, R.; Zhu, R.; Zhang, F.; et al. Dithieno (3,2-b:2', $\left.3^{\prime}-\mathrm{d}\right)$ pyrrol Fused Nonfullerene Acceptors Enabling Over 13\% Efficiency for Organic Solar Cells. Adv. Mater. 2018, 30, 1707150. [CrossRef] [PubMed]

6. Fan, Q.; Zhu, Q.; Xu, Z.; Su, W.; Chen, J.; Wu, J.; Guo, X.; Ma, W.; Zhang, M.; Li, Y. Chlorine substituted 2D-conjugated polymer for high-performance polymer solar cells with $13.1 \%$ efficiency via toluene processing. Nano Energy 2018, 48, 413-420. [CrossRef]

7. Sun, L.; Xu, X.; Song, S.; Zhang, Y.; Miao, C.; Liu, X.; Xing, G.; Zhang, S. Medium-Bandgap Conjugated Polymer Donors for Organic Photovoltaics. Macromol. Rapid Commun. 2019, 40, e1900074. [CrossRef]

8. Li, W.; Chen, M.; Cai, J.; Spooner, E.L.; Zhang, H.; Gurney, R.S.; Liu, D.; Xiao, Z.; Lidzey, D.G.; Ding, L.; et al. Molecular Order Control of Non-fullerene Acceptors for High-Efficiency Polymer Solar Cells. Joule 2019, 3 , 819-833. [CrossRef]

9. Zheng, B.; Huo, L.; Li, Y. Benzodithiophenedione-based polymers: Recent advances in organic photovoltaics. NPG Asia Mater. 2020, 12, 1-22. [CrossRef]

10. Zhang, W.; Li, Z.; Zhao, S.; Xu, Z.; Qiao, B.; Song, D.; Wageh, S.; Al-Ghamdi, A.A. With PBDB-T as the Donor, the PCE of Non-Fullerene Organic Solar Cells Based on Small Molecule INTIC Increased by 52.4\%. Materials 2020, 13, 1324. [CrossRef]

11. Liu, X.; Li, Y.; Ding, K.; Forrest, S. Energy Loss in Organic Photovoltaics: Nonfullerene Versus Fullerene Acceptors. Phys. Rev. Appl. 2019, 11, 024060. [CrossRef]

12. Lu, L.; Zheng, T.; Wu, Q.; Schneider, A.M.; Zhao, D.; Yu, L. Recent Advances in Bulk Heterojunction Polymer Solar Cells. Chem. Rev. 2015, 115, 12666-12731. [CrossRef] [PubMed]

13. Ameri, T.; Li, N.; Brabec, C.J. Highly efficient organic tandem solar cells: A follow up review. Energy Environ. Sci. 2013, 6, 2390. [CrossRef]

14. Meng, L.; Zhang, Y.; Wan, X.; Li, C.; Zhang, X.; Wang, Y.; Ke, X.; Xiao, Z.; Ding, L.; Xia, R.; et al. Organic and solution-processed tandem solar cells with $17.3 \%$ efficiency. Science 2018, 361, 1094-1098. [CrossRef] [PubMed]

15. Genene, Z.; Mammo, W.; Wang, E.; Andersson, M.R. Recent Advances in n-Type Polymers for All-Polymer Solar Cells. Adv. Mater. 2019, 31, e1807275. [CrossRef] [PubMed]

16. Lee, J.W.; Choi, Y.S.; Ahn, H.; Jo, W.H. Ternary Blend Composed of Two Organic Donors and One Acceptor for Active Layer of High-Performance Organic Solar Cells. ACS Appl. Mater. Interfaces 2016, 8, 10961-10967. [CrossRef]

17. Yang, L.; Yan, L.; You, W. Organic Solar Cells beyond One Pair of Donor-Acceptor: Ternary Blends and More. J. Phys. Chem. Lett. 2013, 4, 1802-1810. [CrossRef]

18. Yang, L.; Zhou, H.; Price, S.C.; You, W. Parallel-like Bulk Heterojunction Polymer Solar Cells. J. Am. Chem. Soc. 2012, 134, 5432-5435. [CrossRef]

19. Ameri, T.; Khoram, P.; Min, J.; Brabec, C.J. Organic Ternary Solar Cells: A Review. Adv. Mater. 2013, 25, 4245-4266. [CrossRef] 
20. Bi, P.; Hao, X.-T. Versatile Ternary Approach for Novel Organic Solar Cells: A Review (Solar RRL 1/2019). Sol. RRL 2019, 3, 3. [CrossRef]

21. Gasparini, N.; Salleo, A.; McCulloch, I.; Baran, D. The role of the third component in ternary organic solar cells. Nat. Rev. Mater. 2019, 4, 229-242. [CrossRef]

22. Huang, H.; Yang, L.; Sharma, B. Recent advances in organic ternary solar cells. J. Mater. Chem. A 2017, 5, 11501-11517. [CrossRef]

23. Lu, L.; Kelly, M.A.; You, W.; Yu, L. Status and prospects for ternary organic photovoltaics. Nat. Photonics 2015, 9, 491-500. [CrossRef]

24. Lu, L.; Chen, W.; Xu, T.; Yu, L. High-performance ternary blend polymer solar cells involving both energy transfer and hole relay processes. Nat. Commun. 2015, 6, 7327. [CrossRef] [PubMed]

25. Xu, H.; Ohkita, H.; Tamai, Y.; Benten, H.; Ito, S. Interface Engineering for Ternary Blend Polymer Solar Cells with a Heterostructured Near-IR Dye. Adv. Mater. 2015, 27, 5868-5874. [CrossRef]

26. An, Q.; Zhang, J.; Zhang, J.; Tang, W.; Deng, Z.; Hu, B. Versatile ternary organic solar cells: A critical review. Energy Environ. Sci. 2016, 9, 281-322. [CrossRef]

27. Yan, H.; Li, D.; Zhang, Y.; Yang, Y.; Wei, Z. Rational Design of Ternary-Phase Polymer Solar Cells by Controlling Polymer Phase Separation. J. Phys. Chem. C 2014, 118, 10552-10559. [CrossRef]

28. Huang, J.-S.; Goh, T.; Li, X.; Sfeir, M.Y.; Bielinski, E.A.; Tomasulo, S.; Lee, M.L.; Hazari, N.; Taylor, A.D. Polymer bulk heterojunction solar cells employing Förster resonance energy transfer. Nat. Photonics 2013, 7, 479-485. [CrossRef]

29. Hwang, H.; Sin, D.H.; Park, C.; Cho, K. Ternary Organic Solar Cells Based on a Wide-Bandgap Polymer with Enhanced Power Conversion Efficiencies. Sci. Rep. 2019, 9, 12081. [CrossRef]

30. Sun, Y.; Welch, G.C.; Leong, W.L.; Takacs, C.J.; Bazan, G.C.; Heeger, A.J. Solution-processed small-molecule solar cells with 6.7\% efficiency. Nat. Mater. 2011, 11,44-48. [CrossRef]

31. Qi, X.; Lo, Y.-C.; Zhao, Y.; Xuan, L.; Ting, H.-C.; Wong, K.-T.; Rahaman, M.; Chen, Z.; Xiao, L.; Qu, B. Two Novel Small Molecule Donors and the Applications in Bulk-Heterojunction Solar Cells. Front. Chem. 2018, 6, 6. [CrossRef] [PubMed]

32. An, Q.; Zhang, F.; Li, L.; Wang, J.; Sun, Q.; Zhang, J.; Tang, W.; Deng, Z. Simultaneous Improvement in Short Circuit Current, Open Circuit Voltage, and Fill Factor of Polymer Solar Cells through Ternary Strategy. ACS Appl. Mater. Interfaces 2015, 7, 3691-3698. [CrossRef] [PubMed]

33. Bi, P.-Q.; Wu, B.; Zheng, F.; Xu, W.-L.; Yang, X.; Feng, L.; Zhu, F.; Hao, X.-T. An Obvious Improvement in the Performance of Ternary Organic Solar Cells with "Guest" Donor Present at the "Host" Donor/Acceptor Interface. ACS Appl. Mater. Interfaces 2016, 8, 23212-23221. [CrossRef] [PubMed]

34. Honda, S.; Nogami, T.; Ohkita, H.; Benten, H.; Ito, S. Improvement of the Light-Harvesting Efficiency in Polymer/Fullerene Bulk Heterojunction Solar Cells by Interfacial Dye Modification. ACS Appl. Mater. Interfaces 2009, 1, 804-810. [CrossRef]

35. Wang, Y.; Wang, T.; Chen, J.; Kim, H.D.; Gao, P.; Wang, B.; Iriguchi, R.; Ohkita, H. Quadrupolar D-A-D diketopyrrolopyrrole-based small molecule for ternaryblend polymer solar cells. Dye. Pigment. 2018, 158, 213-218. [CrossRef]

36. Baran, D.; Ashraf, R.S.; Hanifi, D.A.; Abdelsamie, M.; Gasparini, N.; Rohr, J.A.; Holliday, S.; Wadsworth, A.; Lockett, S.; Neophytou, M.; et al. Reducing the efficiency-stability-cost gap of organic photovoltaics with highly efficient and stable small molecule acceptor ternary solar cells. Nat. Mater. 2016, 16, 363-369. [CrossRef] [PubMed]

37. Ho, D.; Ozdemir, R.; Kim, H.; Earmme, T.; Usta, H.; Kim, C. BODIPY-Based Semiconducting Materials for Organic Bulk Heterojunction Photovoltaics and Thin-Film Transistors. ChemPlusChem 2018, 84, 18-37. [CrossRef] [PubMed]

38. Chen, J.J.; Conron, S.M.; Erwin, P.; Dimitriou, M.; McAlahney, K.; Thompson, M.E. High-Efficiency BODIPY-Based Organic Photovoltaics. ACS Appl. Mater. Interfaces 2014, 7, 662-669. [CrossRef] [PubMed]

39. Singh, S.P.; Gayathri, T. Evolution of BODIPY Dyes as Potential Sensitizers for Dye-Sensitized Solar Cells. Eur. J. Org. Chem. 2014, 2014, 4689-4707. [CrossRef]

40. Wanwong, S.; Sangkhun, W.; Wootthikanokkhan, J. The effect of co-sensitization methods between N719 and boron dipyrromethene triads on dye-sensitized solar cell performance. RSC Adv. 2018, 8, 9202-9210. [CrossRef] 
41. Gkini, K.; Verykios, A.; Balis, N.; Kaltzoglou, A.; Papadakis, M.; Adamis, K.S.; Armadorou, K.-K.; Soultati, A.; Drivas, C.; Gardelis, S.; et al. Enhanced Organic and Perovskite Solar Cell Performance through Modification of the Electron-Selective Contact with a Bodipy-Porphyrin Dyad. ACS Appl. Mater. Interfaces 2019, 12, 1120-1131. [CrossRef] [PubMed]

42. Gautam, P.; Dhokale, B.; Mobin, S.M.; Misra, R. Ferrocenyl BODIPYs: Synthesis, structure and properties. RSC Adv. 2012, 2, 12105. [CrossRef]

43. Purc, A.; Sobczyk, K.; Sakagami, Y.; Ando, A.; Kamada, K.; Gryko, D. Strategy towards large two-photon absorption cross-sections for diketopyrrolopyrroles. J. Mater. Chem. C 2015, 3, 742-749. [CrossRef]

44. Wanwong, S.; Surawatanawong, P.; Khumsubdee, S.; Kanchanakungwankul, S.; Wootthikanokkhan, J. Synthesis, optical, and electrochemical properties, and theoretical calculations of BODIPY containing triphenylamine. Heteroat. Chem. 2016, 27, 306-315. [CrossRef]

45. Sengupta, S.; Athresh, E.U.; Pandey, U.K. Regioisomeric donor-acceptor-donor triads based on benzodithiophene and BODIPY with distinct optical properties and mobilities. RSC Adv. 2016, 6, 73645-73649. [CrossRef]

46. Bonnier, C.; Machin, D.D.; Abdi, O.; Koivisto, B. Manipulating non-innocent ?-spacers: The challenges of using 2,6-disubstituted BODIPY cores within donor-acceptor light-harvesting motifs. Org. Biomol. Chem. 2013, 11, 3756. [CrossRef]

47. Yang, J.; Devillers, C.H.; Fleurat-Lessard, P.; Jiang, H.; Wang, S.; Gros, C.P.; Gupta, G.; Sharma, G.D.; Xu, H.-J. Carbazole-based green and blue-BODIPY dyads and triads as donors for bulk heterojunction organic solar cells. Dalton Trans. 2020, 49, 5606-5617. [CrossRef]

48. Min, J.; Ameri, T.; Gresser, R.; Lorenz-Rothe, M.; Baran, D.; Troeger, A.; Sgobba, V.; Leo, K.; Riede, M.K.; Guldi, D.M.; et al. Two Similar Near-Infrared (IR) Absorbing Benzannulated Aza-BODIPY Dyes as Near-IR Sensitizers for Ternary Solar Cells. ACS Appl. Mater. Interfaces 2013, 5, 5609-5616. [CrossRef]

49. Wanwong, S.; Khomein, P.; Thayumanavan, S. BODIPY dyads and triads: Synthesis, optical, electrochemical and transistor properties. Chem. Central J. 2018, 12, 60. [CrossRef]

50. Doumon, N.Y.; Dryzhov, M.V.; Houard, F.; Le Corre, V.M.; Chatri, A.R.; Christodoulis, P.; Koster, L.J.A. Photostability of Fullerene and Non-Fullerene Polymer Solar Cells: The Role of the Acceptor. ACS Appl. Mater. Interfaces 2019, 11, 8310-8318. [CrossRef]

51. Gregory, D.G.; Lu, L.; Kiely, C.J.; Snyder, M.A. Interfacial Stabilization of Metastable $\mathrm{TiO}_{2}$ Films. J. Phys. Chem. C 2017, 121, 4434-4442. [CrossRef]

52. Reese, M.O.; A Gevorgyan, S.; Jørgensen, M.; Bundgaard, E.; Kurtz, S.R.; Ginley, D.S.; Olson, D.C.; Lloyd, M.T.; Morvillo, P.; Katz, E.A.; et al. Consensus stability testing protocols for organic photovoltaic materials and devices. Sol. Energy Mater. Sol. Cells 2011, 95, 1253-1267. [CrossRef]

53. Liu, J.; Chen, S.; Qian, D.; Gautam, B.; Yang, G.; Zhao, J.; Bergqvist, J.; Zhang, F.; Ma, W.; Ade, H.; et al. Fast charge separation in a non-fullerene organic solar cell with a small driving force. Nat. Energy 2016, 1, 16089. [CrossRef]

54. Liu, S.; Yuan, J.; Deng, W.; Luo, M.; Xie, Y.; Liang, Q.; Zou, Y.; He, Z.; Wu, H.; Cao, Y. High-efficiency organic solar cells with low non-radiative recombination loss and low energetic disorder. Nat. Photonics 2020, 14, 300-305. [CrossRef]

55. Yang, D.; Wang, Y.; Sano, T.; Gao, F.; Sasabe, H.; Kido, J. A minimal non-radiative recombination loss for efficient non-fullerene all-small-molecule organic solar cells with a low energy loss of $0.54 \mathrm{eV}$ and high open-circuit voltage of 1.15 V. J. Mater. Chem. A 2018, 6, 13918-13924. [CrossRef]

56. Yang, C.; Zhang, J.; Liang, N.; Yao, H.; Wei, Z.; He, C.; Yuan, X.; Hou, J. Effects of energy-level offset between a donor and acceptor on the photovoltaic performance of non-fullerene organic solar cells. J. Mater. Chem. A 2019, 7, 18889-18897. [CrossRef]

57. Liu, W.; Yao, J.; Zhan, C. A Novel BODIPY-Based Low-Band-Gap Small-Molecule Acceptor for Efficient Non-fullerene Polymer Solar Cells. Chin. J. Chem. 2017, 35, 1813-1823. [CrossRef]

58. Elumalai, N.K.; Uddin, A. Open circuit voltage of organic solar cells: An in-depth review. Energy Environ. Sci. 2016, 9, 391-410. [CrossRef]

59. Zheng, Y.; Goh, T.; Fan, P.; Shi, W.; Yu, J.; Taylor, A.D. Toward Efficient Thick Active PTB7 Photovoltaic Layers Using Diphenyl Ether as a Solvent Additive. ACS Appl. Mater. Interfaces 2016, 8, 15724-15731. [CrossRef] 
60. Luck, K.A.; Sangwan, V.K.; Hartnett, P.E.; Arnold, H.N.; Wasielewski, M.R.; Marks, T.J.; Hersam, M.C. Correlated In Situ Low-Frequency Noise and Impedance Spectroscopy Reveal Recombination Dynamics in Organic Solar Cells Using Fullerene and Non-Fullerene Acceptors. Adv. Funct. Mater. 2017, 27, 1703805. [CrossRef]

61. Li, J.; Liang, Z.; Peng, Y.; Lv, J.; Ma, X.; Wang, Y.; Xia, Y. 36\% Enhanced Efficiency of Ternary Organic Solar Cells by Doping a NT-Based Polymer as an Electron-Cascade Donor. Polymers 2018, 10, 703. [CrossRef] [PubMed]

62. Xie, Y.; Yang, F.; Li, Y.; Uddin, M.A.; Bi, P.; Fan, B.; Cai, Y.; Hao, X.-T.; Woo, H.Y.; Li, W.; et al. Morphology Control Enables Efficient Ternary Organic Solar Cells. Adv. Mater. 2018, 30, 30. [CrossRef] [PubMed]

63. Mai, J.; Lu, H.; Lau, T.-K.; Peng, S.-H.; Hsu, C.S.; Hua, W.; Zhao, N.; Xiao, X.; Lu, X. High efficiency ternary organic solar cell with morphology-compatible polymers. J. Mater. Chem. A 2017, 5, 11739-11745. [CrossRef]

64. Mai, J.Q.; Lau, T.K.; Xiao, T.; Su, C.J.; Jeng, U.S.; Zhao, N.; Xiao, X.D.; Lu, X.H. A ternary morphology facilitated thick-film organic solar cell. Rsc Adv. 2015, 5, 88500-88507. [CrossRef]

65. Yang, X.; Zheng, F.; Xu, W.; Bi, P.; Feng, L.; Liu, J.; Hao, X.-T. Improving the Compatibility of Donor Polymers in Efficient Ternary Organic Solar Cells via Post-Additive Soaking Treatment. ACS Appl. Mater. Interfaces 2016, 9, 618-627. [CrossRef] [PubMed]

66. Bonasera, A.; Giuliano, G.; Arrabito, G.; Pignataro, B. Tackling Performance Challenges in Organic Photovoltaics: An Overview about Compatibilizers. Molecules 2020, 25, 2200. [CrossRef]

67. Du, X.; Lin, H.; Chen, X.; Tao, S.; Zheng, C.-J.; Zhang, X. Ternary organic solar cells with a phase-modulated surface distribution via the addition of a small molecular luminescent dye to obtain a high efficiency over 10.5\%. Nanoscale 2018, 10, 16455-16467. [CrossRef]

68. Sun, Y.; Chien, S.-C.; Yip, H.-L.; Chen, K.-S.; Zhang, Y.; Davies, J.A.; Chen, F.-C.; Lin, B.; Jen, A.K.-Y. Improved thin film morphology and bulk-heterojunction solar cell performance through systematic tuning of the surface energy of conjugated polymers. J. Mater. Chem. 2012, 22, 5587. [CrossRef]

69. An, Q.; Zhang, F.; Sun, Q.; Zhang, M.; Zhang, J.; Tang, W.; Yin, X.; Deng, Z. Efficient organic ternary solar cells with the third component as energy acceptor. Nano Energy 2016, 26, 180-191. [CrossRef]

70. Neumann, A.; Good, R.; Hope, C.; Sejpal, M. An equation-of-state approach to determine surface tensions of low-energy solids from contact angles. J. Colloid Interface Sci. 1974, 49, 291-304. [CrossRef]

71. Li, D.; Neumann, A. A reformulation of the equation of state for interfacial tensions. J. Colloid Interface Sci. 1990, 137, 304-307. [CrossRef]

72. Li, D.; Neumann, A. Contact angles on hydrophobic solid surfaces and their interpretation. J. Colloid Interface Sci. 1992, 148, 190-200. [CrossRef]

73. Sumita, M.; Sakata, K.; Asai, S.; Miyasaka, K.; Nakagawa, H. Dispersion of fillers and the electrical conductivity of polymer blends filled with carbon black. Polym. Bull. 1991, 25, 265-271. [CrossRef]

74. Zhu, K.; Tang, D.; Zhang, K.; Wang, Z.; Ding, L.; Liu, Y.; Yuan, L.; Fan, J.; Song, B.; Zhou, Y.; et al. A two-dimension-conjugated small molecule for efficient ternary organic solar cells. Org. Electron. 2017, 48, 179-187. [CrossRef]

75. Mohapatra, A.A.; Kim, V.; Puttaraju, B.; Sadhanala, A.; Jiao, X.; McNeill, C.R.; Friend, R.H.; Patil, S. Förster Resonance Energy Transfer Drives Higher Efficiency in Ternary Blend Organic Solar Cells. ACS Appl. Energy Mater. 2018, 1, 4874-4882. [CrossRef]

(C) 2020 by the authors. Licensee MDPI, Basel, Switzerland. This article is an open access article distributed under the terms and conditions of the Creative Commons Attribution (CC BY) license (http://creativecommons.org/licenses/by/4.0/). 